\title{
PENGARUH PERAN KEPEMIMPINAN, KOMUNIKASI DAN LINGKUNGAN KERJA TERHADAP KINERJA PEGAWAI PADA UPTD PUSKESMAS KECAMATAN KLARI KABUPATEN KARAWANG
}

\author{
Eneng Sukmayanti \\ enengsukmayanti77@gmail.com
}

\begin{abstract}
ABSTRAK
The purpose of this study is to obtain empirical evidence and to find clarity of phenomena and conclusions about the influence of leadership role, communication, and work environment on employee performance at UPTD Puskesmas Kecamatan Klari Kabupaten Karawang.

This thesis is expected to contribute to the development of management science, especially as a contribution of scientific literature in human resources management, as reference material in scientific writing, as an information material, both for leaders and colleagues in District Health Office Karawang in the implementation of performance-based management, As a material consideration and input in making decisions and determine the direction of policy.

The research is done by using quantitative method with descriptive and verification method, that is collecting, presenting, analyzing and doing hypothesis testing, and making conclusion and suggestion. Based on the results of the research analysis, the following conclusions are obtained:

1. The correlation of leadership (X1) with communication (X2) has a correlation coefficient value $(r)$ of 0.512 and if interpreted by the closeness of relationship between these two variables has a fairly strong level of relationship (Sugiyono, 2005:255) and unidirectional because the value is positive. This shows that if leadership increases then communication will also increase. Conversely, if communication increases then leadership will also increase.

2. Communication correlation (X2) with work environment (X3) has correlation coefficient (r) value of 0.343 and if interpreted with the closeness of relationship of these two variables have a low level of relationship (Sugiyono, 2005:255) and unidirectional because the value is positive. This shows that if communication increases then the work environment will also increase. Conversely, if the work environment increases then communication will also increase.

3. The correlation of leadership (X1) with work environment (X3) has a correlation coefficient value (r) of 0.359 and if interpreted by the closeness of the relationship of these two variables have a low level of relationship (Sugiyono, 2005:255) and unidirectional because the value is positive. This shows that if leadership increases then the work environment will also increase. Conversely, if the work environment increases then leadership will also increase.

4. The magnitude of the influence of leadership role on employee performance is $24.4 \%$. Based on the findings of this study can be concluded that the hypothesis of research that states "leadership has significant effect on employee performance" is acceptable.

5. The magnitude of communication effect on employee performance is $14.2 \%$.
\end{abstract}

99. Jurnal Manajemen \& Bisnis Kreatif 
Based on the findings of this study can be concluded that the hypothesis of research that states "communication has significant effect on employee performance" is acceptable.

6. The amount of work environment influence on employee performance is $13.4 \%$. Based on the findings of this study it can be concluded that the research hypothesis which states "work environment contribute significantly to the performance of employees" is acceptable.

7. Simultaneously leadership (X1), communications (X2), and work environment (X3) have a significant effect on employee performance (Y) of $52.0 \%$. The remaining $48.0 \%$ is the effect that comes from other factors.

Keywords : Role of Leadership, Communication, Work Environment, Employee Performance

\section{Pendahuluan}

Pembangunan kesehatan diarahkan untuk mencapai tujuan nasional sebagaimana diamanatkan dalam pembukaan Undang-Undang Dasar 1945, alinea IV, yaitu : "melindungi segenap bangsa Indonesia dan seluruh tumpah darah Indonesia, memajukan kesejahteraan umum, mencerdaskan kehidupan bangsa, dan ikut menciptakan ketertiban dunia berdasarkan kemerdekaan, perdamaian abadi, dan keadilan sosial".

Pembangunan kesehatan pada hakekatnya adalah upaya yang dilaksanakan oleh semua komponen Bangsa Indonesia yang bertujuan untuk meningkatkan kesadaran, kemauan, dan kemampuan hidup sehat bagi setiap orang agar terwujud derajat kesehatan masyarakat yang setinggi-tingginya, sebagai investasi bagi pembangunan sumber daya manusia yang produktif secara sosial dan ekonomis.

Salah satu bentuk upaya pemerintah dalam menyelenggarakan pembangunan kesehatan kepada masyarakat yaitu dengan dikeluarkannya Peraturan Menteri Kesehatan Republik Indonesia Nomor 75 Tahun 2014 tentang Pusat Kesehatan Masyarakat (Puskesmas) yang merupakan fasilitas pelayanan kesehatan yang menyelenggarakan upaya kesehatan masyarakat dan upaya kesehatan perseorangan tingkat pertama dengan lebih mengutamakan upaya kuratif (pengobatan), preventif (upaya pencegahan), promotif (peningkatan kesehatan) dan rehabilitasi (pemulihan kesehatan) untuk mencapai derajat kesehatan masyarakat yang setinggi-tingginya di wilayah kerjanya.

Puskesmas sebagai salah satu instansi milik pemerintah juga dapat mengalami peningkatan atau penurunan kinerja pegawai. Banyaknya program puskesmas yang harus dilaksanakan menuntut seluruh pegawai puskesmas memiliki kinerja yang tinggi (Sulaeman, 2009). Idealnya, kinerja pegawai dikatakan baik jika baik secara kuantitas, yaitu jumlah pekerjaan yang terealisasikan sesuai target, baik secara kualitas, yaitu mutu penyelesaian pekerjaan baik dan baik secara ketepatan waktu, yaitu sesuai dengan waktu yang direncanakan (Mangkunegara, 2010).

Lingkungan dan iklim kerja yang baik akan mendorong pegawai senang bekerja dan puas dengan pekerjaannya, sehingga meningkatkan rasa tanggung jawab untuk melakukan pekerjaan dengan lebih baik menuju ke arah peningkatan kinerja (Sedarmayanti, 2011). Jika salah satu faktor pengukuran kinerja di atas mengalami kendala, akan menimbulkan suatu masalah pada hasil kerja pegawai.

100. Jurnal Manajemen \& Bisnis Kreatif 
Berdasarkan pengamatan pra penelitian, di UPTD Puskesmas Kecamatan Klari Kabupaten Karawang peran kepemimpinanya belum maksimal, pemimpin belum menggunakan kewenangannya dengan baik. Hal tersebut terlihat dengan adanya pembagian tugas yang tidak merata. Masih dijumpai pegawai yang mempunyai kinerja rendah dibiarkan tanpa mendapat teguran atau sanksi tegas. Sementara itu ada pegawai yang diberi tugas dan tanggung jawab banyak menjadi kurang fokus terhadap pekerjaan yang diberikan pimpinan. Akibatnya pegawai bekerja tidak sesuai dengan tugas dan tanggungjawabnya, sehingga dapat berpengaruh terhadap kinerja pegawai.

Fenomena lain yang terjadi pada UPTD Puskesmas Kecamatan Klari Kabupaten Karawang adalah masalah komunikasi. Komunikasi yang terjadi belum lah efektif, sehingga arus pesan yang disampaikan diantara pegawai belum dapat diterima secara baik, kadangkala keliru menafsirkan informasi yang disampaikan pimpinan ataupun rekan kerja. Diduga perbedaan informasi dalam penerimaan pesan dan kurang tercapainya kesamaan makna menjadi penyebabnya.

Selain kepemimpinan dan komunikasi, faktor lain yang perlu diperhatikan organisasi dalam meningkatkan kinerja pegawai adalah lingkungan kerja. Lingkungan kerja merupakan segala sesuatu disekitar pekerja dan dapat berpengaruh terhadap pekerjanya. Dengan lingkungan kerja yang nyaman diharapkan memacu pegawai untuk bekerja lebih baik sehingga kinerja yang dicapai dapat maksimal. Lingkungan kerja sendiri terdiri atas lingkungan fisik dan lingkungan nonfisik yang melekat dengan aktivitas dalam menjalankan tugas dan fungsinya. Sedarmayanti (2009 : 21) menyatakan bahwa lingkungan kerja adalah keseluruhan alat perkakas dan bahan yang dihadapi, lingkungan sekitarnya dimana seorang bekerja, metode kerjanya, serta pengaturan kerjanya baik sebagai perseorangan maupun sebagai kelompok.Berdasarkan pengamatan pra penelitian, di UPTD Puskesmas Kecamatan Klari Kabupaten Karawang sendiri lingkungan fisik maupun nonfisik cukup memadai, akan tetapi belum sempurna. Sebagai contoh, lahan parkir yang sempit, ruang kerja yang belum memadai, masih kurang lengkapnya peralatan pada bagian pelayanan kesehatan dan perkantoran seperti kurangnya pengadaan alat pemeriksaan pasien dan jumlah komputer menyebabkan kinerja pegawai tidak maksimal.

Tujuan Penelitian Penelitian ini dilakukan dengan tujuan untuk mengetahui, menganalisis dan menjelaskan :

1. Peran kepemimpinan pada UPTD Puskesmas Kecamatan Klari Kabupaten Karawang;

2. Komunikasi pada UPTD Puskesmas Kecamatan Klari Kabupaten Karawang;

3. Lingkungan kerja pada UPTD Puskesmas Kecamatan Klari Kabupaten Karawang;

4. Kinerja Pegawai pada UPTD Puskesmas Kecamatan Klari Kabupaten Karawang;

5. Besaran korelasi peran kepemimpinan dan komunikasi pada UPTD Puskesmas kecamatan Klari Kabupaten Karawang;

6. Besaran korelasi komunikasi dan lingkungan kerja pada UPTD Puskesmas Kecamatan Klari Kabupaten Karawang;

7. Besaran korelasi peran kepemimpinan dan lingkungan kerja pada UPTD Puskesmas Kecamatan Klari Kabupaten Karawang; 
8. Besaran pengaruh peran kepemimpinan, komunikasi dan lingkungan kerja secara parsial terhadap kinerja pegawai pada UPTD Puskesmas Kecamatan Klari Kabupaten Karawang;

9. Besaran pengaruh peran kepemimpinan, komunikasi dan lingkungan kerja secara simultan terhadap kinerja pegawai pada UPTD Puskesmas Kecamatan Klari Kabupaten Karawang.

\section{Landasan Teori}

\subsection{Peran Kepemimpinan}

Siswanto (2005:154) menyatakan bahwa kepemimpinan adalah sifat dan perilaku untuk mempengaruhi para bawahan agar mampu bekerja sama sehingga membentuk jalinan kerja yang harmonis dengan pertimbangan aspek efisien dan efektif untuk mencapai tingkat produktivitas kerja sesuai dengan yang telah ditetapkan.

Sedarmayanti (2010:120) memberikan pengertian kepemimpinan adalah sebagai berikut :

1. Proses dalam memengaruhi orang lain agar mau atau tidak melakukan sesuatu yang diinginkan;

2. Hubungan interaksi antar pengikut dan pemimpin dalam mencapai tujuan bersama;

3. Proses memberi arti terhadap usaha kolektif, dan mengakibatkan kesediaan untuk melakukan usaha yang diinginkan untuk pencapaian sasaran.

Menurut Kartini Kartono (2011:93), fungsi dari kepemimpinan ialah memandu, menuntun, membimbing, membangun, memberi atau membangunkan motivasimotivasi kerja, mengemudikan organisasi, menjalin jaringan-jaringan komunikasi yang baik, memberikan supervise/pengawasan yang efisien, dan dalam kepemimpinannya harus mampu melaksanakan aktivitas yang mampu mengubah perilaku orang lain sesuai dengan keinginannya atau organisasi yang telah disepakati bersama.

Dari beberapa pengertian tersebut di atas, maka dapat disimpulkan bahwa kepemimpinan adalah kemampuan seseorang untuk mempengaruhi, mengarahkan dan memotivasi seseorang, kelompok atau organisasi agar mau mengikuti dan menuruti apa yang telah menjadi keputusan atau ketetapan untuk mencapai tujuan organisasi.

Dimensi yang dipakai sebagai panduan dalam penelitian ini adalah pendapat dari Senge dalam Sedarmayanti (2009:144-145) yang menyatakan tentang tugas/pekerjaan pemimpin meliputi : Pemimpin sebagai perancang, Pemimpin sebagai guru, Pemimpin sebagai pelayan.

\subsection{Komunikasi}

Menurut William Albig (1983:13), komunikasi adalah proses pengoperan lambing yang berarti diantara individu-individu.

Pawito dan C Sardjono (1994:12) mendefinisikan komunikasi sebagai suatu proses dengan mana suatu pesan dipindahkan atau dioperkan (lewat suatu saluran) dari suatu sumber kepada penerima dengan maksud mengubah perilaku, perubahan dalam pengetahuan, sikap dana tau perilaku over lainnya. 
Sedangkan menurut Redi Panuju (2001:1), komunikasi merupakan sistem aliran yang menghubungkan dan kinerja antar bagian dalam organisasi sehingga menghasilkan suatu sinergi.

Lain halnya dengan Alo Liliweri (2003:4) mengartikan komunikasi sebagai pengalihan suatu pesan dari satu sumber kepada penerima agar dapat dipahami.

Dari beberapa pendapat tersebut dapat ditarik kesimpulan bahwa komunikasi adalah pesan yang disampaikan kepada komunikan (penerima) dari komunikator (sumber) melalui saluran tertentu baik secara langsung/tidak langsung untuk tujuan memberikan efek/dampak kepada komunikan sesuai dengan yang diinginkan komunikator.

Dimensi yang dipakai sebagai panduan dalam penelitian ini adalah pendapat dari Weisbord (2003:100) yang menyatakan tentang dimensi komunikasi meliputi :

1. Komunikasi antar individu, unit organisasi, orang-orang dan organisasi secara keseluruhan;

2. Kualitas komunikasi, saling ketergantungan, konflik, dan kerja sama.

\subsection{Lingkungan Kerja}

Menurut Mardiana (2005:15), lingkungan kerja adalah lingkungan dimana pegawai melakukan pekerjaannya sehari-hari. Lingkungan kerja yang kondusif memberikan rasa aman dan memungkinkan para pegawai untuk dapat berkerja optimal.

Lingkungan kerja dapat mempengaruhi emosi pegawai. Jika pegawai menyenangi lingkungan kerja dimana dia bekerja, maka pegawai tersebut akan betah di tempat kerjanya untuk melakukan aktivitas sehingga waktu kerja dipergunakan secara efektif dan optimis prestasi kerja pegawai juga tinggi. Lingkungan kerja tersebut mencakup hubungan kerja yang terbentuk antara sesama pegawai dan hubungan kerja antar bawahan dan atasan serta lingkungan tempat pegawai bekerja.

Menurut Sedarmayanti (2009:21) definisi lingkungan kerja adalah keseluruhan alat perkakas dan bahan yang dihadapi, lingkungan sekitarnya dimana seseorang bekerja, metode kerjanya, serta pengaturan kerjanya baik sebagai perseorangan maupun sebagai kelompok.

Lingkungan kerja menurut Rivai (2006:165) adalah keseluruhan sarana dan prasarana yang ada di sekitar karyawan yang sedang melakukan pekerjaan itu sendiri. Lingkungan kerja ini meliputi tempat kerja, fasilitas dan alat bantu kerja, kebersihan, pencahayaan dan ketenangan.

Dari beberapa pendapat di atas, dapat disimpulkan bahwa lingkungan kerja merupakan segala sesuatu yang ada di sekitar karyawan pada saat bekerja, baik yang berbentuk, langsung atau tidak langsung, yang dapat mempengaruhi dirinya dan pekerjaannya saat bekerja.

Dimensi yang dipakai sebagai panduan dalam penelitian ini adalah menurut pendapat dari Sedarmayanti (2001:146), yang menjadi dimensi lingkungan kerja yaitu :

1. Penerangan.

2. Suhu udara.

3. Suara bising.

4. Penggunaan warna.

103. Jurnal Manajemen \& Bisnis Kreatif 
5. Ruang gerak yang diperlukan

6. Keamanan kerja.

7. Hubungan karyawan.

\subsection{Kinerja Pegawai}

Sutermeister (2001:45) menyatakan, "We have recognized that employee performance depends on both motivation and ability". Kinerja menurut Sutermeister di atas merujuk kinerja Pegawai Negeri Sipil tergantung motivasi dan kemampuannya. Sejalan dengan pendapat Sutermeister tersebut, Hoy dan Miskel (2001:116) dengan mengutip pendapat Vroom mengemukakan bahwa, "Performance $=f$ (ability $x$ motivation). "Kinerja merupakan fungsi dari kemampuan dan motivasi". Atau dengan kata lain, kinerja individu sebagai anggota kelompok organisasi ditentukan oleh kemampuan dan kemauannya dalam melaksanakan tugas.

Berkenaan dengan kinerja Smith dan Waldron (2002:393) menyatakan bahwa kinerja adalah, "output drived from processes, human or otherwise". Selanjutnya, Smith menyatakan bahwa kinerja merupakan gambaran keseluruhan dari organisasi. Pedoman dalam suatu penilaian merupakan hal yang dapat membantu untuk memberikan penilaian tersebut.Yang menjadi pedoman dalam penilaian kinerja adalah patokan untuk membandingkan kinerja yang nampak sekarang dengan kinerja ideal yang diharapkan. Dengan demikian, maka perlu adanya patokan kinerja sebagai bandingnya atau standarnya.

Dari Definisi-definisi di atas dapat disimpulkan kinerja merupakan perilaku yang menunjukkan hasil pekerjaan yang dilakukan oleh pegawai atau merupakan kontribusi yang diberikan oleh pegawai atas pelaksanaan suatu pekerjaan terhadap organisasinya dalam waktu tertentu

Untuk mengukur Kinerja karyawan digunakan dimensi alat ukur sesuai teori menurut Gomes (2003:134) memperluas yaitu:

1. Quantity of work (kuantitas pekerjaan).

2. Quality of work (kualitas pekerjaan).

3. Job Knowledge (pengetahuan akan pekerjaan).

4. Creativeness (kreativitas).

5. Cooperation (kerjasama).

6. Dependability (dapat diandalkan).

7. Initiative (inisiatif).

8. Personal Qualities (kualitas personal).

9. Tidiness/Groomy (tingkat kerapian).

10. Loyality (tingkat ketaatan).

\subsection{Kerangka pemikiran}

\subsubsection{Pengaruh Peran Kepemimpinan terhadap Kinerja Pegawai}

Henry Simamora dalam Mangkunegara (2010:14) menyebutkan bahwa kinerja dapat dipengaruhi oleh faktor individu dan organisasi. Yang termasuk kedalam faktor individu adalah kemampuan dan keahlian sedangkan faktor organisasi yang dapat mempengaruhi kinerja adalah kepemimpinan.

Begitupula menurut A. Dale Timple dalam Mangkunegara (2010:15), faktorfaktor yang mempengaruhi kinerja karyawan terdiri dari faktor internal dan faktor 
eksternal. Faktor internal (disposisional) yaitu faktor yang dihubungkan dengan sifat-sifat seseorang, sedangkan faktor eksternal yaitu faktor-faktor yang mempengaruhi kinerja seseorang yang berasal dari lingkungan seperti pimpinan, fasilitas kerja, dan iklim organisasi. (A.A. Anwar Prabu Mangkunegara, 2010:15)

Sejalan dengan penelitian yang telah dilakukan oleh Kiswanto (2010), kinerja dapar dipengaruhi oleh faktor kepemimpinan. Sejalan dengan penelitian yang telah dilakukan oleh Soegihartono (2012), Hadayani (2010), Kurniawan (2012), Harimisa (2013) dan Dewi Lina (2014) yang membahas tentang kepemimpinan, hasil penelitiannya menyatakan bahwa kepemimpinan berpengaruh positif terhadap kinerja dan produktifitas pegawai. Kepemimpinan mempunyai kekuatan untuk mempengaruhi, mendorong dan mengajak bawahan untuk mengerjakan sesuatu atau tidak mengerjakan sesuatu yang diperintahkannya untuk mencapai tujuan. Dalam kepemimpinan terdapat hubungan antar manusia yaitu hubungan mempengaruhi dari pimpinan dan hubungan kepatuhan dan ketaatan para bawahan karena dipengaruhi oleh kewibawaan pemimpin.

\subsubsection{Pengaruh Komunikasi terhadap Kinerja Pegawai}

Menurut Romli (2011:2) bahwa "komunikasi organisasi pengiriman dan penerimaan berbagai pesan organisasi di dalam kelompok formal maupun informal dari suatu organisasi". Komunikasi dapat juga terjadi di dalam organisasi, dalam kenyataan walaupun alat dan cara komunikasi dan teknologi informasi telah mengalami kemajuan pesat, tetapi komunikasi antar orang-orang di dalam sebuah organisasi tetap diperlukan serta memiliki peran penting dalam upaya organisasi mencapai tujuan..

Komunikasi organisasi memiliki pengaruh yang kuat terhadap pencapaian kinerja pegawai di suatu lembaga atau organisasi. Hal ini semakin dipertegas oleh pendapat Sedarmayanti (2007:200) yang menyatakan bahwa : Komunikasi merupakan hal penting dalam penciptaan dan pemeliharaan sistem pengukuran kinerja. Komunikasi sebaiknya dari berbagai arah, berasal dari top-down, bottomup dan secara horizontal berada di dalam dan lintas organisasi.

Dalam rangka pengambilan keputusan serta pelaksanaan kegiatan pimpinan, baik berupa perencanaan, pengorganisasian, penggerakkan, dan pengendalian, maka senantiasa dipelihara adanya komunikasi yang setepat tepatnya. Peranan komunikasi organisasi sangat penting dalam upaya meningkatkan kemampuan pegawai menuju tercapainya produktivitas dan kinerja suatu organisasi.

\subsubsection{Pengaruh Lingkungan Kerja terhadap Kinerja Pegawai}

Kondisi lingkungan kerja yang berbeda pada setiap organisasi dapat memberikan tingkat kepuasan yang berbeda pula bagi karyawan, sehingga prestasi kerja dalam menyelesaikan tugas yang dibebankan padanya juga berbeda. Yang harus diusahakan untuk memperbaiki metode kerja dalam suatu organisasi atau tempat kerja yang lain adalah menjamin agar para karyawan dapat bekerja dan melaksanakan tugasnya dalam keadaan yang memenuhi persyaratan, sehingga mereka dapat melakukan tugasnya tanpa mengalami hambatan.

Lingkungan kerja akan sangat berpengaruh terhadap prestasi kerja menyelesaikan tugas yang dibebankan kepadanya. Lingkungan kerja yang buruk dipandang oleh banyak ahli sebagai hal yang tidak ekonomis, karena merupakan penyebab utama pemborosan waktu dan hal-hal lainnya yang

105. Jurnal Manajemen \& Bisnis Kreatif 
berakibat hasil kerja (output) yang dihasilkan karyawan akan menurun. Setiap orang, baik secara individu maupun kelompok memberikan reaksi dengan sensitifitas atau kepekaan yang cukup tinggi terhadap iklim psikologis, misalnya cahaya lampu yang kurang terang, kamar yang pengap, kursi yang kurang enak diduduki, hal ini secara drastis dapat meruntuhkan moral kerja atau mengurangi efektifitas dan efisiensi kerja para karyawan.

\subsubsection{Pengaruh Peran Kepemimpinan, Komunikasi, dan Lingkungan Kerja secara Simultan terhadap Kinerja Pegawai}

Dalam usaha memaksimalkan kegunaan dari semua sarana yang ada dan dalam usaha menggerakkan potensi manusia sebagai sumber daya ke arah pemanfaatan yang optimal, maka konsep kepemimpinan, komunikasi dan kondisi tempat kerja merupakan perilaku seseorang dalam memimpin organisasi dan karyawannya. Kepemimpinan melibatkan penggunaan pengaruh dan karenanya semua hubungan dapat merupakan upaya kepemimpinan, menyangkut juga tujuan oranisasi dan masyarakat.

Komunikasi diperlukan untuk menjalin hubungan saling menghargai, hormatmenghormati sesamanya, toleransi dari hati ke hati, dalam rangka satu tujuan untuk mensukseskan pekerjaan dengan baik (sesuai harapan bagi kemajuan organisasi). Komunikasi juga diperlukan untuk menyatukan persepsi pegawai dalam mencapai tujuan yang hakiki pada organisasi untuk menerima dan mengolah ide-ide konstruktif dari pegawai. Komunikasi dalam suatu pekerjaan dapat dianalisis dari tiga tingkatan, yaitu komunikasi individu, komunikasi dalam kelompok, dan komunikasi keorganisasian. Hal ini berarti bahwa semua sumber daya manusia dituntut untuk menjadi orang yang komunikatif yang harus memiliki banyak informasi untuk disampaikan kepada orang lain. Dengan adanya hubungan yang komunikasi dalam suatu organisasi akan dapat meningkatkan kinerja pegawai.

Lingkungan tempat bekerja sangat mempengaruhi pegawai, diantaranya lingkungan tempat bekerja. Pada umumnya pegawai menghendaki tempat bekerja yang cukup terang, udaranya selalu segar dan jam kerjanya tidak terlalu lama. Memberikan tempat kerja yang menyenangkan berarti menimbulkan perasaan yang tidak mudah bosan pada diri pegawai, sehingga dengan cara demikian dapat mengurangi atau menghindari pemborosan waktu dan biaya, merosotnya kesehatan dan banyaknya kecelakaan kerja.

\section{Metode Penelitian}

Tujuan studi dari penelitian ini adalah deskriptif dan verifikatif. Penelitian deskriptif adalah penelitian yang bertujuan untuk memperoleh deskripsi tentang ciri-ciri variabel kepemimpinan, komunikasi,Lingkungan kerja dan kinerja pegawai. Sifat penelitian verifikatif adalah untuk menguji korelasi antara variabel kepemimpinan dan komunikasi serta pengaruh kepemimpinan dan lingkungan kerja terhadap kinerja pegawai.

\subsection{Populasi dan Sampel}

Populasi penelitian yang diteliti adalah Pegawai pada UPTD Puskesmas Kecamatan Klari Kabupaten Karawang sebanyak 100 orang.

Penentuan besarnya jumlah sampel yang diperlukan dalam penelitian ini menggunakan metode sampling jenuh. Sampling jenuh adalah teknik penentuan 
sampel bila semua anggota populasi digunakan sebagai sampel. Hal ini sering dilakukan bila jumlah populasi relatif kecil, kurang dari 30 orang. Istilah lain sampel jenuh adalah sensus, dimana semua anggota populasi dijadikan sampel. (Sugiyono, 2013:68). Berdasarkan jumlah populasi yang ada, maka sampel yang digunakan yaitu sebanyak 38 orang.

\subsection{Teknik Pengumpulan Data}

Pengumpulan data dilakukan dengan cara penelitian lapangan (field research), melalui penyebaran kuesioner yang terstruktur. Sedangkan untuk pengujian instrumen kuisioner dilakukan melalui uji validitas, reliabilitas dan uji normalitas.

\subsection{Rancangan Analisis dan Uji Hipotesis}

\subsubsection{Rancangan Analisis}

Dalam menggambarkan keadaan Kepemimpinan, Motivasi Kerja dan Kinerja Pegawai digunakan analisis deskriptif. Adapun langkah-langkahnya adalah sebagai berikut :

a. Analisis Tabulasi Frekuensi

b. Analisis Rentang Skala

Analisis Verifikatif digunakan untuk mengetahui hubungan dan pengaruh antar variabel. Untuk menggambarkan korelasi antara kepemimpinan dan motivasi kerja menggunakan analisis korelasi produk momen sedangkan pengaruh variabel kepemimpinan dan motivasi kerja terhadap kinerja pegawai menggunakan analisis jalur.

Data variabel yang terkumpul melalui kuesioner dalam penelitian ini berbentuk data ordinal, sedangkan untuk menganalisis dengan analisis jalur diperlukan data dengan ukuran paling tidak berskala interval. Oleh karena itu, data dinaikan menjadi data interval dengan method of succesive interval (MSI).

\subsubsection{Uji Hipotesis}

1. Terdapat korelasi antara peran kepemimpinan dan komunikasi pada UPTD Puskesmas Kecamatan Klari Kabupaten Karawang

2. Terdapat korelasi antara komunikasi dan lingkungan kerja pada UPTD Puskesmas Kecamatan Klari Kabupaten Karawang

3. Terdapat korelasi antara peran kepemimpinan dan lingkungan kerja pada UPTD Puskesmas Kecamatan Klari Kabupaten Karawang

4. Terdapat pengaruh peran kepemimpinan terhadap kinerja pegawai Pada UPTD Puskesmas Kecamatan Klari Kabupaten Karawang

5. Terdapat pengaruh komunikasi terhadap kinerja pegawai Pada UPTD Puskesmas Kecamatan Klari Kabupaten Karawang.

6. Terdapat pengaruh lingkungan kerja terhadap kinerja pegawai Pada UPTD Puskesmas Kecamatan Klari Kabupaten Karawang

7. Terdapat pengaruh secara simultan antara kepemimpinan, komunikasi, dan lingkunganterhadap kinerja pegawaiPada UPTD Puskesmas Kecamatan Klari Kabupaten Karawang.

\section{Hasil Penelitian dan Pembahasan 4.1. Pengujian Instrumen}

107. Jurnal Manajemen \& Bisnis Kreatif 


\section{Uji Validitas}

Berdasarkan hasil uji validitas untuk semua variabel item pernyataan kuisioner dinyatakan valid karena $\mathrm{r}$ hitung $>0,3$.

\section{Uji Reliabilitas}

Berdasarkan hasil pengolahan data diperoleh bahwa semua instrument reliable karena cronbach Alpha $(\alpha)>0,6$ dengan masing-masing nilai untuk variabel peran kepemimpinan, Komunikasi, Lingkungan Kerja dan Kinerja Pegawai adalah 0,$887 ; 0,908 ; 0,868$ dan 0,931 .

\section{Uji Normalitas}

Hasil perhitungan data menunjukkan bahwa p-value untuk Variabel peran kepemimpinan $\left(\mathrm{X}_{1}\right)$, Komunikasi $\left(\mathrm{X}_{2}\right)$, Lingkungan Kerja $\left(\mathrm{X}_{3}\right)$ dan Kinerja Pegawai (Y) adalah 0,933. Nilai p-value $>0,05$, sehingga semua variabel mengikuti distribusi normal (Sudjana, 2005: 273).

\subsubsection{Pembahasan Deskriptif}

Hasil penelitian yang telah dideskripsikan di atas, dengan mengacu pada metode yang digunakan, selanjutnya dilakukan pembahasan deskriptif atas hasil penelitian tersebut, sebagai berikut:

1. Variabel kepemimpinan berada pada rentang skala baik. Hal ini ditunjukkan dengan pilihan responden yang berada pada kategori baik terhadap variabel kepemimpinan. Persepsi pegawai mengenai kepemimpinan secara umum sudah baik. Namun ada juga beberapa indikator menurut persepsi pegawai masih rendah yaitu mengembangkan visi dan misi.

2. Variabel komunikasi $\left(\mathrm{X}_{2}\right)$ dalam rentang skala berada pada skala baik. Hal ini ditunjukkan dengan pilihan responden yang berada pada kategori tinggi terhadap variabel komunikasi. Artinya bahwa komunikasi sudah baik dan sesuai dengan kebutuhan dan harapan organisasi. Namun walaupun komunikasi secara umum sudah berada pada posisi baik, masih terdapat beberapa indikator yang dinilai masih rendah yaitu pada dimensi komunikasi antar individu, unit organisasi serta orang-orang dalam organisasi secara keseluruhan yaitu indikator instruksi pimpinan dapat diterima dengan baik.

3. Variabel lingkungan kerja $\left(\mathrm{X}_{3}\right)$. Skala ini menunjukan bahwa lingkungan kerja pegawai jika dituangkan pada rentang skala berada pada skala baik. Artinya bahwa lingkungan kerja pegawai di UPTD Puskesmas Kecamatan Klari Kabupaten Karawang telah baik. Namun masih ada indikator lingkungan kerja yang nilainya masih rendah yaitu adanya toleransi dengan rekan kerja. Sehingga indikator inilah yang menjadi permasalahan dalam organisasi yang perlu diperbaiki dan ditingkatkan.

4. Kinerja Pegawai $\left(\mathrm{X}_{4}\right)$ : bahwa kinerja pegawai di UPTD Puskesmas Kecamatan Klari Kabupaten Karawang telah baik. Namun masih ada beberapa indikator kinerja pegawai yang nilainya masih rendah yaitu hubungan dengan rekan kerja, kerjasama dengan pimpinan, dan tingkat kerapian. Sehingga indikatorindikator inilah yang menjadi permasalahan dalam organisasi yang perlu diperbaiki dan ditingkatkan

\subsubsection{Pembahasan Verifikatif}

108. Jurnal Manajemen \& Bisnis Kreatif 
1. Korelasi kepemimpinan $\left(X_{1}\right)$ dengan komunikasi $\left(X_{2}\right)$ mempunyai nilai koefisien korelasi (r) sebesar 0,512 dan jika diinterpretasikan dengan keeratan hubungan kedua variabel ini mempunyai tingkat hubungan yang cukup kuat (Sugiyono, 2005 : 255) dan searah karena nilainya positif. Menurut Abdullah Syarif dalam Jurnal Al-Ishlah (volume $6: 2014$ ) agar dapat menjalankan kepemimpinannya, seorang pimpinan setidaknya harus memiliki kompetensi dasar, yakni 1) mendiagnosis, 2) mengadaptasi, dan 3) mengkomunikasikan. Kemampuan diagnosis merupakan kemampuan kognitif yang dapat memahami situasi saat sekarang dan apa yang diharapkan pada masa yang akan datang. Kompetensi mengadaptasi adalah kemampuan seseorang menyesuaikan perilakunya dengan lingkungannya. Sedangkan kompetensi mengkomunikasikan terkait dengan kemampuan seseorang dalam menyampaikan pesan-pesannya agar dapat dipahami orang lain dengan baik dan jelas. Hal tersebut sejalan dengan apa yang dikatakan Nelson dan Quick (2006:250) bahwa komunikasi adalah untuk membangkitkan pengertian bersama kepada orang lain. Demikian juga Jennifer M. George (2006:437) yang mendefinisikan bahwa komunikasi adalah membagi informasi antara dua orang atau lebih atau kelompok untuk mencapai pemahaman bersama

2. Korelasi komunikasi (x2) dengan lingkungan kerja (x3) mempunyai nilai koefisien korelasi (r) sebesar 0,343 dan jika diinterpretasikan dengan keeratan hubungan kedua variabel ini mempunyai tingkat hubungan yang rendah (Sugiyono, 2005 : 255) dan searah karena nilainya positif. Hasil temuan penelitian ini sejalan atau mendukung pernyataan dari Gorda (2004) yang mengatakan bahwa yang mempengaruhi semangat kerja karyawan salah satunya adalah lingkungan kerja dan komunikasi. Temuan hasil penelitian ini juga mendukung penelitian yang dilakukan Anita Cempaka Putri (2012) yang memaparkan bahwa lingkungan kerja dan komunikasi berpengaruh secara signifikan terhadap kinerja karyawan PT. United Tractors, Tbk Cabang Medan. Hal ini juga mendukung penelitian yang dilakukan Shinta Vesmagita yang menyatakan bahwa komunikasi dan lingkungan kerja berpengaruh terhadap kinerja karyawan PT. Mah Sing Indonesia.

3. Korelasi kepemimpinan $\left(\mathrm{X}_{1}\right)$ dengan lingkungan kerja $\left(\mathrm{X}_{3}\right)$ mempunyai nilai koefisien korelasi (r) sebesar 0,359 dan jika diinterpretasikan dengan keeratan hubungan kedua variabel ini mempunyai tingkat hubungan yang rendah (Sugiyono, 2005 : 255) dan searah karena nilainya positif.. Temuan penelitian ini mendukung penelitian sebelumnya yang dilakukan Deka Agusanti (2009) pada BCA cabang Bengkulu dan Rahma Mareta Furgeri (2011) pada Sekretariat daerah Kota Bengkulu yang menyatakan bahwa terdapat hubungan yang signifikan antara kepemimpinan dan lingkungan kerja.

4. Besaran pengaruh kepemimpinan $\left(\mathrm{X}_{1}\right)$ terhadap kinerja pegawai (Y) mempunyai nilai koefisien determinasi sebesar 0,244 atau berpengaruh sebesar 24,4\%. Henry Simamora dalam Mangkunegara (2010:14) menyebutkan bahwa kinerja dapat dipengaruhi oleh faktor organisasi yaitu kepemimpinan. Begitupula menurut A. Dale Timple dalam Mangkunegara (2010:15), faktor-faktor yang mempengaruhi kinerja yang berasal dari lingkungan seperti pimpinan, fasilitas kerja, dan iklim organisasi. Sejalan dengan penelitian yang telah dilakukan oleh Kiswanto (2010), Soegihartono (2012), Hadayani (2010), Kurniawan (2012), Harimisa (2013) dan Dewi Lina 
(2014) yang membahas tentang kepemimpinan, hasil penelitiannya menyatakan bahwa kepemimpinan berpengaruh positif terhadap kinerja dan produktifitas pegawai.

5. Besaran pengaruh komunikasi ( $\mathrm{x} 2)$ terhadap kinerja pegawai $(\mathrm{Y})$ mempunyai nilai koefisien determinasi sebesar 0,142 atau berpengaruh sebesar 14,2\%. Jadi, komunikasi berkontribusi secara signifikan terhadap kinerja pegawai. Komunikasi organisasi memiliki pengaruh yang kuat terhadap pencapaian kinerja pegawai di suatu lembaga atau organisasi. Hal ini semakin dipertegas oleh pendapat Sedarmayanti (2007:200) yang menyatakan bahwa : Komunikasi merupakan hal penting dalam penciptaan dan pemeliharaan sistem pengukuran kinerjaHal ini sesuai dengan penelitian terdahulu yaitu penelitian Trijaya (2012) mengemukakan kompensasi, pelatihan dan komunikasi berpengaruh signifikan terhadap kinerja pegawai dan yang menjadi variabel dominan adalah kompensasi.

6. Besaran pengaruh lingkungan kerja $\left(\mathrm{X}_{3}\right)$ terhadap kinerja pegawai (Y) mempunyai nilai koefisien determinasi sebesar 0,134 atau berpengaruh sebesar 13,4\%. Jadi, lingkungan kerja berkontribusi secara signifikan terhadap kinerja pegawai. Lingkungan kerja akan sangat berpengaruh terhadap prestasi kerja menyelesaikan tugas yang dibebankan kepadanya. Hasil penelitian tersebut sesuai dengan pendapat para ahli yaitu menurut Wiryawan (2009:6-7) yang menyatakan bahwa kinerja dipengaruhi oleh beberapa faktor yaitu faktor lingkungan internal, lingkungan eksternal dan internal karyawan. Siagian (2002) mengemukakan bahwa kinerja karyawan dipengaruhi oleh beberapa faktor yaitu gaji, lingkungan kerja, budaya organisasi, kepemimpinan dan lain-lain.

7. Nilai koefisien determinasi pengaruh simultan kepemimpinan, komunikasi dan lingkungan kerja sebesar 0,520. Sehingga dapat diartikan bahwa total pengaruh kepemimpinan $\left(\mathrm{X}_{1}\right)$, komunikasi $\left(\mathrm{X}_{2}\right)$ dan lingkungan kerja $\left(\mathrm{X}_{3}\right)$ terhadap kinerja pegawai sebesar 0,520 atau sebesar 52,0\%. Berdasarkan hasil penelitian ini menunjukan bahwa kepemimpinan, komunikasi dan lingkungan kerja memiliki kontribusi terhadap kinerja pegawai (Y) sebesar $52,0 \%$ sedangkan sisanya 0,480 atau sebesar $48,0 \%$ merupakan pengaruh kontribusi variabel lain $(\varepsilon)$ yang tidak diteliti. Hal ini mendukung penelitian yang dilakukan oleh Maria Magdalena Minarsih (2016) yang menyatakan besarnya pengaruh independen variabel lingkungan kerja, komunikasi kerja, dan kepemimpinan secara bersama-sama terhadap kinerja pegawai pada Dinas Kebudayaan dan Pariwisata Kota Semarang adalah sebesar 67,2\% sedangkan sisanya 32,8\% dipengaruhi faktor lain.

\subsection{Pengujian Hipotesis}

\subsubsection{Pengujian Hipotesis Secara Parsial}

Pengujian Pengaruh Secara Parsial Variabel Kepemimpinan $\left(\mathrm{X}_{1}\right)$, Komunikasi $\left(\mathrm{X}_{2}\right)$, dan Lingkungan Kerja $\left(\mathrm{X}_{3}\right)$ terhadap Kinerja Pegawai $(\mathrm{Y})$

\begin{tabular}{|l|l|l|l|l|l|}
\hline $\begin{array}{l}\text { Struktura } \\
\mathbf{l}\end{array}$ & $\begin{array}{l}\mathbf{t} \\
\text { hitung }\end{array}$ & $\mathbf{t}$ tabel & Sig. & $\boldsymbol{\alpha}$ & $\begin{array}{l}\text { Kesimp } \\
\text { ulan }\end{array}$ \\
\hline$\rho_{\text {YX1 }}$ & 4,65 & 1,98 & 0,00 & 0,0 & $\begin{array}{l}\text { Ho } \\
\text { ditolak }\end{array}$ \\
\hline \hline & 7 & 4 & 0 & 5
\end{tabular}

110. Jurnal Manajemen \& Bisnis Kreatif 


\begin{tabular}{|l|l|l|l|l|l|}
\hline مYX2 & 3,07 & 1,98 & 0,00 & 0,0 & Ho \\
& 5 & 4 & 3 & 5 & ditolak \\
\hline \multirow{2}{*}{$\rho_{Y X 3}$} & 3,47 & 1,98 & 0,00 & 0,0 & Ho \\
& 2 & 4 & 1 & 5 & ditolak \\
\hline
\end{tabular}

Sumber : Hasil Pengolahan Data Kuesioner, SPSS, 2017

Dari tabel di atas diperoleh hasil sebagai berikut :

a. Untuk pengaruh parsial kepemimpinan $\left(\mathrm{X}_{1}\right)$ terhadap kinerja pegawai $(\mathrm{Y}), \mathrm{t}_{\text {tabel }}$ $=1,984$. bahwa kepemimpinan $\left(\mathrm{X}_{1}\right)$ secara parsial berpengaruh signifikan terhadap kinerja pegawai (Y).

b. Untuk pengaruh parsial komunikasi $\left(\mathrm{X}_{2}\right)$ terhadap kinerja pegawai $(\mathrm{Y}), \mathrm{t}_{\text {tabel }}=$ 1,984. Dengan demikian dapat disimpulkan bahwa komunikasi $\left(\mathrm{X}_{2}\right)$ secara parsial berpengaruh signifikan terhadap kinerja pegawai (Y).

c. Untuk pengaruh parsial lingkungan kerja $\left(\mathrm{X}_{3}\right)$ terhadap kinerja pegawai $(\mathrm{Y})$, $\mathrm{t}_{\text {tabel }}=1,984$. Tabel 4.27 menunjukkan nilai Sig. $(0,001)<\alpha(0,05)$ dan $t_{\text {hitung }}$ $(3,472)>t_{\text {tabel }}(1,984)$ maka Ho ditolak. Dengan demikian dapat disimpulkan bahwa lingkungan kerja $\left(\mathrm{X}_{3}\right)$ secara parsial berpengaruh signifikan terhadap kinerja pegawai (Y).

\subsubsection{Pengujian Hipotesis Pengaruh Secara Simultan Variabel Kepemimpinan $\left(\mathbf{X}_{1}\right)$, Komunikasi $\left(\mathbf{X}_{2}\right)$, Lingkungan Kerja $\left(\mathbf{X}_{3}\right)$ terhadap Variabel Kinerja Pegawai (Y)}

Tabel 4.42

Pengujian Pengaruh Simultan Variabel $X_{1}, X_{2}$, dan $X_{3}$ Terhadap $Y$

\begin{tabular}{|l|l|l|l|l|l|}
\hline $\begin{array}{l}\text { Mod } \\
\text { el }\end{array}$ & $\begin{array}{l}\text { F }_{\text {hitu }} \\
\text { ng }\end{array}$ & F tabel & Sig. & $\boldsymbol{\alpha}$ & $\begin{array}{l}\text { Kesimp } \\
\text { ulan }\end{array}$ \\
\hline$\rho_{\mathrm{YX}}$ & $\begin{array}{l}34,7 \\
74\end{array}$ & 2,70 & 0,00 & 0,0 & $\begin{array}{l}\text { Ho } \\
\text { litolak }\end{array}$ \\
\hline
\end{tabular}

Sumber : Hasil Pengolahan Data Kuesioner, SPSS, 2017

Pengaruh secara simultan variabel kepemimpinan $\left(\mathrm{X}_{1}\right)$, komunikasi $\left(\mathrm{X}_{2}\right)$, dan lingkungan kerja $\left(\mathrm{X}_{3}\right)$ terhadap kinerja pegawai dapat dilihat pada tabel 4.41, dengan tingkat signifikansi $(\alpha)=5 \%$ dan degree of freedom $(\mathrm{df})=100-2=98$ sehingga diperoleh $F_{\text {tabel }}=2,70$. Tabel 4.41 menunjukkan nilai Sig. sebesar 0,000 lebih kecil dari $\alpha(0,05)$ dan $F_{\text {hitung }}(34,774)>F_{\text {tabel }}(2,70)$, dengan demikian Ho ditolak sehingga dapat disimpulkan bahwa kepemimpinan $\left(\mathrm{X}_{1}\right)$, komunikasi $\left(\mathrm{X}_{2}\right)$ dan lingkungan kerja $\left(\mathrm{X}_{3}\right)$ secara simultan berpengaruh signifikan terhadap kinerja pegawai $(\mathrm{Y})$.

\section{Simpulan dan Saran}

\subsection{Simpulan}

1. Peran kepemimpinan pada UPTD Puskesmas Kecamatan Klari Kabupaten Karawang sudah baik. Namun ada juga beberapa indikator menurut persepsi pegawai masih rendah yaitu mengembangkan visi dan misi. 
2. Komunikasi pada UPTD Puskesmas Kecamatan Klari Kabupaten Karawang sudah baik,. Artinya bahwa komunikasi sudah baik dan sesuai dengan kebutuhan dan harapan organisasi,Namun masih terdapat beberapa indikator yang dinilai masih rendah yaitu pada dimensi komunikasi antar individu, unit organisasi serta orang-orang dalam organisasi secara keseluruhan yaitu indikator instruksi pimpinan dapat diterima dengan jelas.

3. Lingkungan kerja pada UPTD Puskesmas Kecamatan Klari Kabupaten Karawang sudah baik ,Namun masih ada indikator lingkungan kerja yang nilainya masih rendah yaitu adanya toleransi dengan rekan kerja. Sehingga indikator inilah yang menjadi permasalahan dalam organisasi yang perlu diperbaiki dan ditingkatkan.

4. Kinerja Pegawai pada UPTD Puskesmas Kecamatan Klari Kabupaten Karawang sudah baik. Namun masih ada beberapa indikator kinerja pegawai yang nilainya masih rendah yaitu hubungan dengan rekan kerja, kerjasama dengan pimpinan, dan tingkat kerapian. Sehingga indikator-indikator inilah yang menjadi permasalahan dalam organisasi yang perlu diperbaiki dan ditingkatkan.

5. Korelasi kepemimpinan dengan komunikasi mempunyai nilai koefisien korelasi (r) sebesar 0,512 atau 51,2 \% dan jika diinterpretasikan dengan keeratan hubungan kedua variabel ini mempunyai tingkat hubungan yang cukup kuat (Sugiyono, 2005 : 255) dan searah karena nilainya positif. Ini menunjukan bahwa jika kepemimpinan meningkat maka komunikasi juga akan meningkat

6. Korelasi komunikasi dengan lingkungan kerja mempunyai nilai koefisien korelasi (r) sebesar 0,343 atau 34,3\% dan jika diinterpretasikan dengan keeratan hubungan kedua variabel ini mempunyai tingkat hubungan yang rendah (Sugiyono, 2005 : 255) dan searah karena nilainya positif. Ini menunjukan bahwa jika komunikasi meningkat maka lingkungan kerja juga akan meningkat. Sebaliknya jika lingkungan kerja meningkat maka komunikasi juga akan meningkat.

7. Korelasi kepemimpinan dengan lingkungan kerja mempunyai nilai koefisien korelasi (r) sebesar 0,359 atau 35,9\% dan jika diinterpretasikan dengan keeratan hubungan kedua variabel ini mempunyai tingkat hubungan yang rendah (Sugiyono, $2005: 255)$ dan searah karena nilainya positif.

8. Pada penelitian ini diperoleh pengaruh peran kepemimpinan terhadap kinerja pegawai adalah sebesar 24,4\%, pengaruh komunikasi terhadap kinerja pegawai adalah sebesar $14,2 \%$ dan pengaruh lingkungan kerja terhadap kinerja pegawai adalah sebesar $13,4 \%$. Berdasarkan pengolahan data tersebut menunjukan bahwa nilai $24,4 \%>14,2 \%>13,4 \%$. Hal ini menunjukan bahwa peran kepemimpinan lebih besar dan dominan memberikan kontribusi terhadap Kinerja pegawai dibandingkan lingkungan kerja dan komunikasi.

9. Secara simultan kepemimpinan, komunikasi, dan lingkungan kerja berpengaruh secara signifikan terhadap kinerja pegawai sebesar 52,0\%. Sisanya yaitu sebesar 48,0\% merupakan pengaruh yang datang dari faktorfaktor lain. Misalnya: budaya organisasi, iklim organisasi, etos kerja, kompensasi, disiplin kerja, komitmen, loyalitas dll. Berdasarkan temuan penelitian ini dapat disimpulkan bahwa hipotesis penelitian yang menyatakan 
"kepemimpinan, komunikasi, dan lingkungan kerja berkontribusi secara simultan dan signifikan terhadap kinerja pegawai" dapat diterima.

\subsection{Saran}

1. Peran Kepemimpinan di UPTD Puskesmas Kecamatan Kalri Kabupaten Karawang sudah baik tapi di pengembangan Visi dan Misi nilainya paling rendah untuk dapat mengembangkan visi dan misi hendaknya pimpinan mengajak bersama-sama pegawai sehingga adanya keterlibatan karyawan untuk membuat visi dan misi bersama sehingga pegawai akan ikut serta mengembangkan visi dan misi yang telah dibuat bersama.dengan keterlibatan Pegawai akan memiliki keterikatan emosional dan komitmen yang kuat dengan visi dan misi perusahaan. Pegawai merasa memiliki visi dan misi sejalan dengan visi dan misi perusahaan sehingga Pegawai memiliki kepedulian yang tinggi terhadap tugas/pekerjaan perusahaan.

2. Instruksi pimpinan yang dapat diterima dengan jelas tersebut masih menjadi permasalahan dalam organisasi, Selain itu supaya instruksi pimpinan dapat diterima dengan jelas Sebaiknya para Kepala UPTD Puskesmas Kecamatan Klari Kabupaten Karawang dalam memberikan tugas yang perlu dikerjakan kepada pegawai secara langsung tanpa melalui pelimpahan wewenang. Dan ketika memberi tugas, pemimpin berkomunikasi secara langsung dan memberikan perintah secara jelas kepada bawahan. Pimpinan sebaiknya memperhatikan pendapat bawahannya, sehingga bawahan merasa lebih dihargai oleh pimpinan, disamping itu pimpinan hendaknya mau mendengarkan masalah yang dihadapi pegawai. Oleh karena itu hal tersebut dapat dilakukan dengan baik oleh pimpinan, sehingga dapat meningkatkan kinerja pegawainya.

3. Nilainya masih rendah pada lingkungan kerja yaitu adanya toleransi dengan rekan kerja untuk mengoptimalkan toleransi dengan rekan kerja dengan cara karyawan dapat membangun iklim kerja yang menyenangkan yaitu dengan sikap terbuka dan berkomunikasi dengan sesama rekan kerja dan sikap terbuka tersebut memungkinkan karyawan mendapat solusi dari teman kerja ketika mendapat kesulitan dalam bekerja dan akhirnya terbentuk sikap toleransi antara sesama rekan kerja.

4. Kinerja Pegawai Pada UPTD Puskesmas Kecamatan Klari Kabupaten Karawang ada beberapa yang kurang optimal yaitu hubungan dengan rekan kerja, kerjasama dengan pimpinan dan tingkat kerapihan dalam bekerja. Untuk lebih meningkatkan kinerja pegawai diupayakan adanya hubungan yang harmonis dengan rekan kerja dan pimpinan dengan cara adanya komunikasi yang baik kualitas maupun kuantitasnya.Untuk menjalin komunikasi yang baik kualitas maupun kuanitasnya sebaiknya para Kepala UPTD Puskesmas Kecamatan Klari Kabupaten Karawang diharapkan dapat lebih memelihara komunikasi yang efektif antara masing-masing pegawai di seluruh lini manajemen agar hubungan baik terjalin saat menyelesaikan tugas tanpa adanya misscomunication. Pimpinan juga dalam melakukan komunikasi harus lebih terbuka terhadap bawahan, agar lebih jelas dan mudah dipahami. Dalam upaya menghindari konflik, pimpinan dapat membuka forum antara atasan dengan bawahan, dimana bawahan dapat mengungkapkan keluhan-keluhannya sehingga tidak terjadi perselisihan, hal ini dapat menambah kekerabatan antara 
sesama pegawai dan juga antara atasan dengan bawahan. Selain itu juga untuk membina komunikasi antar pegawai dapat terjalin, pimpinan dapat melakukan kegiatan karyawisata dengan kegiatan tersebut di harpakan hubungan dengan rekan kerja akan semakin baik. Selain untuk mengurangi stress kerja tetapi juga untuk memupuk kerja sama dan komunikasi antar pegawai.Untuk meningkatkan tingkat kerapihan dalam bekerja karyawan diberikan pelatihan cara bekerja yang cerdas dan efektif misalnya pelatihan 5S (Seiri, Seiton, Seiso, Seiketsu dan Shitsuke) atau 5R (Ringkas, Rapi, Resik, Rawat dan Rajin )

5. Penelitian lebih lanjut tentang variabel lainnya yang mempengaruhi variabel kinerja pegawai pada UPTD Puskesmas Kecamatan Klari Kabupaten Karawang sehingga diharapkan fungsi dan sistem manajemen dapat berjalan lebih optimal.

\section{DAFTAR PUSTAKA}

Arikunto, S. 2006. Prosedur Penelitiaan Suatu Pendekatan Praktik. PT. Rineka Cipta, Jakarta.

Artina, et all. Pengaruh Kepemimpinan, Budaya Kerja, Lingkungan Kerja terhadap Disiplin Kerja dan Kinerja Personil Polda Riau. Jurnal Tepak Manajemen Bisnis, Vo. VI No. 2 Mei 2014. Hal 9-19.

Dessler, Gary. 2009. Manajemen SDM. Buku 1. Indeks, Jakarta.

Fathoni, Abdurrahmat. 2006. Organisasi dan Manajemen Sumber Daya Manusia. Rineka Cipta, Jakarta.

Gomes, Foustino Cardoso. 2003. Manajemen Sumber Daya Manusia. Andi Offset, Yogyakarta.

Handoko, T. Hani. 2001. Manajemen Personalia dan Sumber Daya Manusia. BPFE, Yogyakarta.

Heidjarachman dan Husnan. 2002. Manajemen Personalia. BPFE, Yogyakarta.

Hoy and Miskel. 2001. Manajemen. Terjemahan: Antariksa et all. Erlangga, Jakarta.

Kartasasmita, Ginandjar. 1997. Administrasi Pembangunan, Perkembangan Pemikiran dan Prakteknya di Indonesia. Cetakan Pertama. LP3ES, Jakarta.

Mangkunegara, A.A. Anwar Prabu. 2001. Manajemen Sumber Daya Manusia Perusahaan. PT. Remaja Rosda Karya, Bandung.

Moelyono, Djokosantoso. 2004. Penerapan Produktivitas dalam Organisasi, Bumi Aksara, Jakarta.

Nawawi, H., 2006. Evaluasi dan Manajemen Kinerja di Lingkungan Perusahaan dan Industri. Cetakan Kesatu. Gajah Mada University Press, Yogyakarta.

Nitisemito, A.S, 2005. Manajemen Personalia (Manajemen Sumber Daya Manusia ). Ghalia Indonesia, Jakarta.

Nurmanto, Safri. 2007. Budaya Organisasi, dari Chester I Barnard ke Michael E. Porter. Selo Soemardjan Research Centre FISIP Universitas Indonesia, Jakarta.

Peraturan Pemerintah RI Nomor 53 Tahun 2010 tentang Disiplin Pegawai Negeri Sipil. 
Prayitno, Widyo Yudo. 2004. Budaya Kerja, Kemampuan dan Komitmen Pegawai Negeri Sipil di Biro Kepegawaian Sekretariat Daerah Provinsi Jawa Timur. Tesis. Program Pascasarjana, Universitas Airlangga, Surabaya.

Rahayu, Kurniasih Panti, 2010. Pengaruh Budaya Kerja dan Kepemimpinan terhadap Kinerja Pegawai di Lingkungan Mahkamah Konstitusi. Tesis. Program Studi Ilmu Administrasi, Universitas Indonesia, Jakarta.

Rivai, Veithzal, 2009. Manajemen Sumber Daya Manusia untuk Perusahaan. Edisi Kedua. Raja Grafindo Persada, Jakarta.

Riduwan dan Kuncoro, 2007. Cara Menggunakan dan Memaknai Analisis Jalur (Path Analysis). Cetakan Pertama. Alfabeta, Bandung.

Robin, Stephan P., 2008. Perilaku Organisasi. Buku 1. Edisi 12. Salemba Empat, Jakarta.

Saydam, Gouzali. 2000. Manajemen Sumber Daya Manusia. Gunung Agung, Jakarta.

Sedarmayanti. 2010. Manajemen Sumber Daya Manusia Reformasi Birokrasi dan Manajemen Pegawai Negeri Sipil. Cetakan Keempat. PT. Refika Aditama, Bandung.

Siagian, Sondang. 2002. Manajemen Sumber Daya Manusia. Bumi Aksara, Jakarta

Siswanto, Bejo. 2005. Manajemen Tenaga Kerja, Rancangan Dalam Pendayungan dan pengembangan Unsur Tenaga Kerja. Sinar Baru, Bandung.

Sugiyono. 2010. Metode Penelitian Administrasi. CV. Alfabeta, Bandung.

Sutermeister. 2001. Manajemen. Erlangga, Jakarta.

The New Grolier Webster International Dictionary of the English Language, 1999. London.

Tris, Laras. 2006. Analisis Pengaruh Komunikasi, Kecerdasan Emosional dan Budaya Organisasi terhadap Kinerja Karyawan (Studi Kasus PT. Pos Indonesia Persero se-Kota Semarang. Tesis. Universitas Diponegoro, Semarang.

Undang-Undang Nomor 8 Tahun 1974 tentang Pokok-Pokok Kepegawaian (Lembaran Negara Republik Indonesia Tahun 1974 Nomor 55, Tambahan Lembaran Negara Republik Indonesia Nomor 3041) sebagaimana telah diubah dengan Undang-Undang Nomor 43 Tahun 1999 (Lembaran Negara Republik Indonesia Tahun 1999 Nomor 169, Tambahan Lembaran Negara Republik Indonesia Nomor 3890).

Wirawan. 2009. Evaluasi Kinerja Sumber Daya Manusia, Teori, Aplikasi, dan Penelitian. Salemba Empat, Jakarta. 